\title{
Labour Market Integration and Public Perceptions of Immigrants: A Comparison between Germany and Spain During the Economic Crisis
}

\author{
Dirk Godenau, Dita Vogel, Vesela Kovacheva, Yan Wu
}

\begin{abstract}
Since the start of the global economic downturn, Germany and Spain have experienced highly-divergent impacts of the crisis on the labour market in general and on immigrant workers in particular. This can be mainly explained by looking at the economic growth patterns prior to the crisis. Spain's higher, more labour-intensive growth was enabled by growth in the labour supply that was fuelled by immigration and fostered by a de facto permissive immigration policy, while restrictive migration policy prevented growth in labour supply in Germany and encouraged more capital-intensive growth in which both Germans with a low level of skills, and immigrants in particular, found it difficult to integrate. We therefore argue that institutional features of the labour market promoted these patterns. The high level of importance of the temporary and informal labour market segments in Spain which were hit hardest by the crisis placed immigrant workers and young workers in a vulnerable position.

The economic crisis has made parts of the population more sceptical about immigration in both countries. However, there appear to be no links between the severity of the crisis and public debates on migration. Although Spain was definitely hit harder by the crisis than Germany, and immigrants were affected more severely, public debates on migration and integration issues seem to be at least as fierce in Germany as in Spain. The legacy of past migrations and migration policies exerts a more significant influence on the public perception of migration as a risk than economic factors do.
\end{abstract}

Keywords: Immigration · Labour market · Economic crisis · Germany · Spain

\section{Introduction}

The global economic crisis affected countries all over the world, and particularly impacted European states with regard to their immigrant populations. However, the effects differed from one country to another - Spain is among those economies which 
were affected more severely, and Germany is among those leading the recovery. In 2010, two years after the outbreak of the global economic crisis in the autumn of 2008 , Germany is showing a relatively favourable employment situation, with only $7 \%$ unemployment, while Spain's unemployment rate tops $20 \%$. The difference is even more marked with regard to foreign nationals: Germany registers decreasing numbers of unemployed foreign nationals, while in Spain these numbers have multiplied. At the same time, a heated debate about integration issues is going on in Germany. Economic meltdown in Spain seems to have swept immigration topics out of the media, and the debate on integration issues is only an emerging topic in the public domain.

In this paper, we sketch the differing effects of the economic crisis on the labour markets in Spain and Germany and explore how it affects immigrant labour market integration and the discussion on immigrants in public debates, referring to Eurostat data and published studies. Labour market developments are conceptualized as the interplay between labour supply and labour demand as influenced by institutional structures, with labour supply being influenced among other things by immigration which is enabled by migration policies, and labour demand being influenced by global and domestic demand for products and services.

We show, firstly, how production and employment developed during the last decade, which encompassed a boom period and a decline period (section 2), before we highlight the impact of restrictive policies on migration (section 3). We then sketch relevant institutional and sectoral features of the labour market comparatively (section 4) in order to explain the general patterns and in particular the differential impact of the economic crisis on the labour market integration of foreign nationals (section 5). Lastly, we question the existence of a close relationship between economic crisis and public debates on immigration (section 6).

\section{Development of growth and employment levels}

For years, the German economy had lower growth rates than the EU average, and considerably lower growth rates than the Spanish economy. Growth rates converged from the last quarter of 2008 onwards (which we consider as the beginning of the global economic crisis). Declines in Gross Domestic Product (GDP) of around $4 \%$ were observed on average in the European Union, Germany and Spain in 2009. Estimates for 2010 indicate a quicker recovery in Germany than in Spain, and Eurostat forecasts that this trend will persist (see Fig. 1).

Behind the growth rates, there are widely-diverging growth patterns in terms of employment and productivity. Prior to the crisis, the Spanish economy grew almost exclusively through expanding employment (annual average of $5.3 \%$ during 1998-2007), creating 6.5 million additional jobs between 1998 and 2007, while real labour productivity per hour worked expanded by an average of only $0.9 \%$ (Godenau 2010: 6-10). Germany's GDP growth added 2.7 million jobs during the same period $(0.8 \%)$, but with a much greater increase in productivity $(1.6 \%)$. The crisis reduced real labour productivity in Germany due to lower hours worked by the aver- 
Fig. 1: Growth rates of GDP volume in Germany and Spain (percentage yearon-year change)

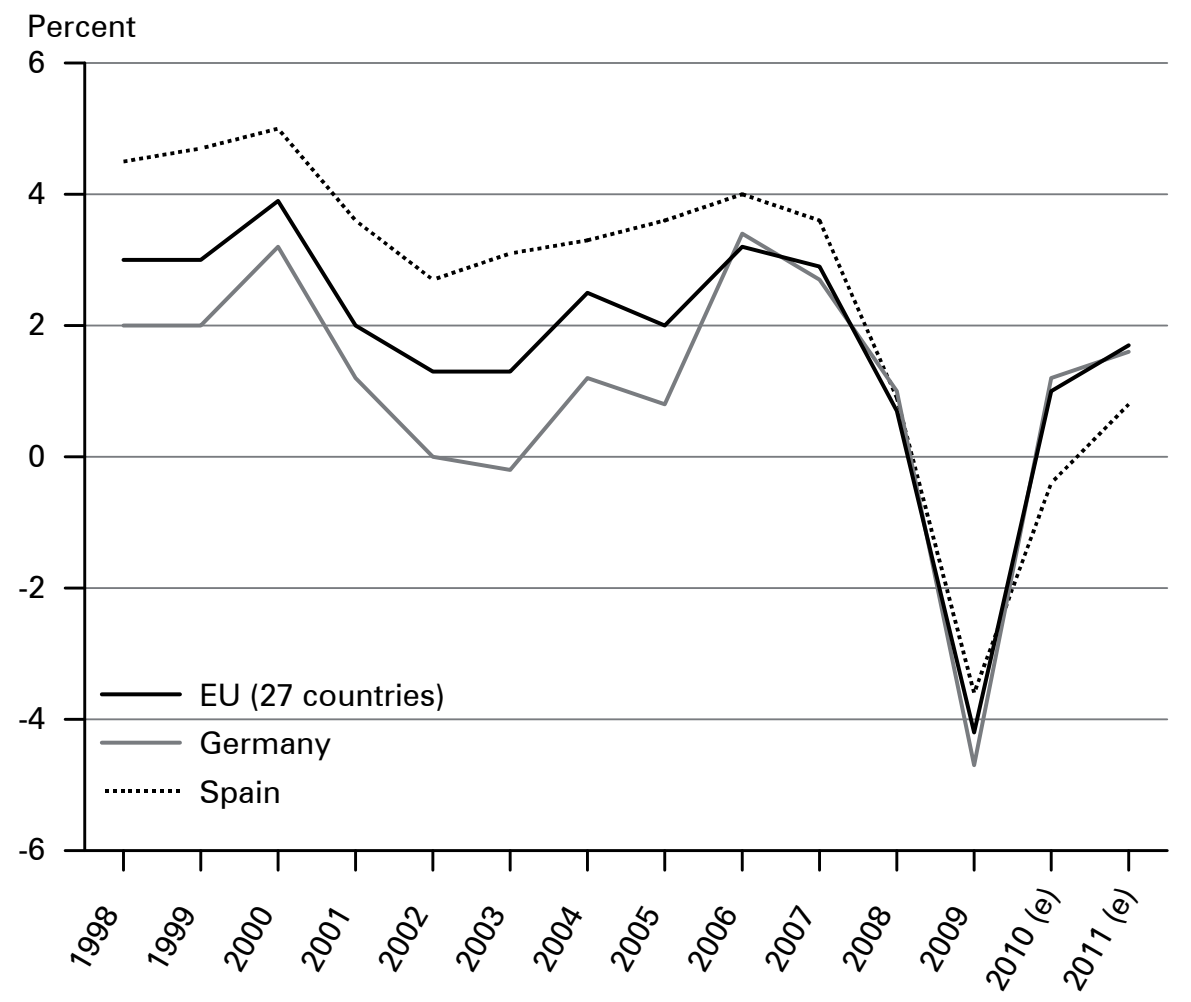

Note: (e) - 2010 and 2011 estimates

Source: Eurostat National Accounts

age employee. Measured productivity in Spain grew as the destruction of employment was more intense than the reduction in output.

The different patterns of growth can be partly attributed to different sectoral growth patterns. Table 1 shows the sectoral distribution of employment growth (see Table 1).

The economic sectors contributed differently towards growth at the beginning of the millennium, and they have been affected differently by the international crisis. Construction and real estate activities in Spain lost nearly a quarter of their total employment between 2008 and 2009. Prices and production in these sectors had been inflated, creating a 'bubble'. The bursting of the bubble marked the start of the crisis. Agriculture, manufacturing and 'other services' are among the sectors that shed large numbers of workers in Germany. In general, sectors with the most considerable employment growth before the crisis lost most employment during the crisis in both countries. 
Tab. 1: Employment shares and growth rates in Germany and Spain*

\begin{tabular}{|c|c|c|c|c|}
\hline \multirow[b]{2}{*}{ Sectors (NACE 1) ${ }^{1}$} & \multicolumn{2}{|c|}{ Share 2007} & \multicolumn{2}{|c|}{ Growth 1998-2007 } \\
\hline & Germany & Spain & Germany & Spain \\
\hline Total - all NACE 1 activities & 100.0 & 100.0 & 7.5 & 47.4 \\
\hline Agriculture, forestry and fishing & 2.2 & 4.5 & -13.1 & -13.0 \\
\hline Industry (except construction) & 23.2 & 16.0 & -2.4 & 14.6 \\
\hline Construction & 6.6 & 13.3 & -19.4 & 97.0 \\
\hline Services & 67.9 & 66.2 & 16.3 & 57.8 \\
\hline $\begin{array}{l}\text { Wholesale and retail trade; repair of motor vehicles, motorcycles } \\
\text { and personal and household goods }\end{array}$ & 14.0 & 15.4 & 4.8 & 37.4 \\
\hline Hotels and restaurants & 3.8 & 7.1 & 27.5 & 72.1 \\
\hline Transport, storage and communication & 5.6 & 5.8 & 12.3 & 43.1 \\
\hline Financial intermediation & 3.4 & 2.5 & 3.9 & 44.4 \\
\hline Real estate, renting and business activities & 10.3 & 9.9 & 52.8 & 119.8 \\
\hline Public administration and defence; compulsory social security & 7.6 & 6.1 & -5.0 & 42.1 \\
\hline $\begin{array}{l}\text { Education; health; other service activities; activities of households; } \\
\text { extra-territorial organizations }\end{array}$ & 23.3 & 19.5 & 21.7 & 61.1 \\
\hline Education & 5.9 & 5.5 & 14.4 & 34.8 \\
\hline Health and social work & 11.4 & 6.0 & 28.2 & 65.1 \\
\hline Other community, social and personal service activities & 5.4 & 4.2 & 15.4 & 65.1 \\
\hline \multirow[t]{2}{*}{ Activities of households } & 0.5 & 3.8 & 55.5 & 106.9 \\
\hline & \multicolumn{2}{|c|}{ Share 2009} & \multicolumn{2}{|c|}{ Growth 2008-2009 } \\
\hline Sectors (NACE 2) & Germany & Spain & Germany & Spain \\
\hline Total - All NACE 2 activities & 100.0 & 100.0 & -0.2 & -6.8 \\
\hline Agriculture, forestry and fishing & 1.7 & 4.2 & -6.0 & -4.0 \\
\hline Industry (except construction) & 22.1 & 14.7 & -2.6 & -13.3 \\
\hline Construction & 6.6 & 10.0 & 0.1 & -23.0 \\
\hline Wholesale and retail trade; repair of motor vehicles and motorcycles & 13.5 & 15.7 & -0.5 & -7.1 \\
\hline Transportation and storage & 4.7 & 4.8 & -1.2 & -5.6 \\
\hline Accommodation and food service activities & 3.9 & 7.5 & 2.1 & -2.2 \\
\hline Information and communication & 3.2 & 2.7 & -0.4 & -7.8 \\
\hline Financial and insurance activities & 3.5 & 2.5 & 0.6 & -6.6 \\
\hline Real estate activities & 0.7 & 0.5 & 23.4 & -23.2 \\
\hline Professional, scientific and technical activities & 4.9 & 4.5 & 3.3 & -2.7 \\
\hline Administrative and support service activities & 5.0 & 4.7 & 4.5 & -3.1 \\
\hline Public administration and defence; compulsory social security & 7.2 & 7.2 & 0.2 & 7.1 \\
\hline Education & 6.2 & 6.1 & 1.3 & 1.0 \\
\hline Human health and social work activities & 11.8 & 7.0 & 3.6 & 4.9 \\
\hline Arts, entertainment and recreation & 1.4 & 1.6 & 0.6 & -1.7 \\
\hline Other service activities & 3.0 & 2.2 & -13.6 & -1.6 \\
\hline $\begin{array}{l}\text { Activities of households as employers; undifferentiated goods- and } \\
\text { services-producing activities of households for own use }\end{array}$ & 0.5 & 3.8 & -6.0 & -3.6 \\
\hline
\end{tabular}

* Comparison of employment of all persons age 15 years and older as measured by Eurostat in Labour Force Surveys

1 Different classifications due to changes in Statistical Classification of Economic Activities in the EU (NACE 1 - NACE 2)

Source: own calculation based on Eurostat Labour Force Surveys 


\section{Development of migration under the influence of migration policies}

Both Germany and Spain are characterized by a progressively ageing work force. Spain still has a slightly younger population, but fertility reduction has been profound, and has placed Spain among the countries with the lowest fertility rate in the world (less than 1.2 children per woman 1995-2000), despite a small rise observed in 2006 (1.35 children per woman) (Roig Vila/Castro Martín 2007: 351). Educational levels are high and continue to grow among the younger population in both countries, conditioning rising wage and employment expectations according to educational level. Both countries continuously had a large number of unemployed persons, but encountered considerable difficulties when it came to organising the labour market integration of these spare workers.

In such a context, the exceptional Spanish employment growth at the beginning of the millennium would not have been possible without immigration, which was enabled by a de facto permissive immigration policy. New legal immigration opportunities for gaining access to the labour market were opened up by the immigration law of 2004 through the introduction of annual quotas for labour immigration. During the extraordinary regularisation campaign of 2005, about 692,000 irregular migrants were regularized. In spite of somewhat increasing efforts to combat the shadow economy, the informal sector is still relatively large, offering employment opportunities for irregular migrants. Spanish policies towards irregular residents are characterized by focusing on preventing new entries over the borders and securing migrants' basic rights such as healthcare and schooling for minors already in the country.

During the crisis, the Spanish Government introduced 'pay-to-go' programmes targeting third-country nationals, thereby subsidizing the return of unemployed immigrants and promising them favourable return options after five years, but programme take-up was limited to a small number of individuals. ${ }^{1}$ Recruitment of new foreign workers has been reduced by cutting the quota in the immigration law and suspending the bilateral hiring agreements with countries of origin (Ferrero-Turrión/ López-Sala 2010: 174).

In contrast, German migration policies did not allow for growth in the labour supply through immigration in the past. The 2005 Immigration Act ('Zuwanderungsgesetz') provided a more consistent, simplified framework for immigration, but it basically consolidated the previous restrictive policies with regard to labour market access for regular migrants. New opportunities were opened up only for highlyskilled immigrants with job offers involving high earnings and for foreign graduates of German universities. The Labour Migration Control Act ('Arbeitsmigrationssteuerungsgesetz') of 2009 demonstrates the Government's efforts in calling for

1 1,821 immigrants participated in the Voluntary Return Programme for Immigrants in Socially Precarious Situations (PREVIE) in 2008, and the number increased to 3,297 in 2009. The Programme for the Early Payment of Unemployment Benefits to Foreigners (APRE) was taken up by 8,724 applicants in 2009, plus 1,581 relatives who accompanied these people back home (Ferrero-Turrión/López-Sala 2010: 172). 
action to make sure that the 'best brains' are brought into the German labour market. According to this legal amendment, access to the labour market was facilitated both for highly-skilled workers from the new Member States (EU-12), which were still subject to transitional restrictions, and also for specified classes of third-country nationals (Koehler et al. 2010: 29). Efforts to combat employment in the shadow economy were consolidated. In 2004, labour market control was integrated in the 'Finanzkontrolle Schwarzarbeit' (directly translated as Financial Control of Illicit Employment), when civil inspection units became part of the police-like inspection units of the customs office. Being already quite restrictive, migration policies did not change during the crisis. ${ }^{2}$

The two countries implemented different policies with regard to intra-EU labour migration for the new Member States of the European Union. Germany made full use of transitional periods for seven years, restricting access to the labour market

Fig. 2: Net immigration in Germany and Spain, 1998 to 2008

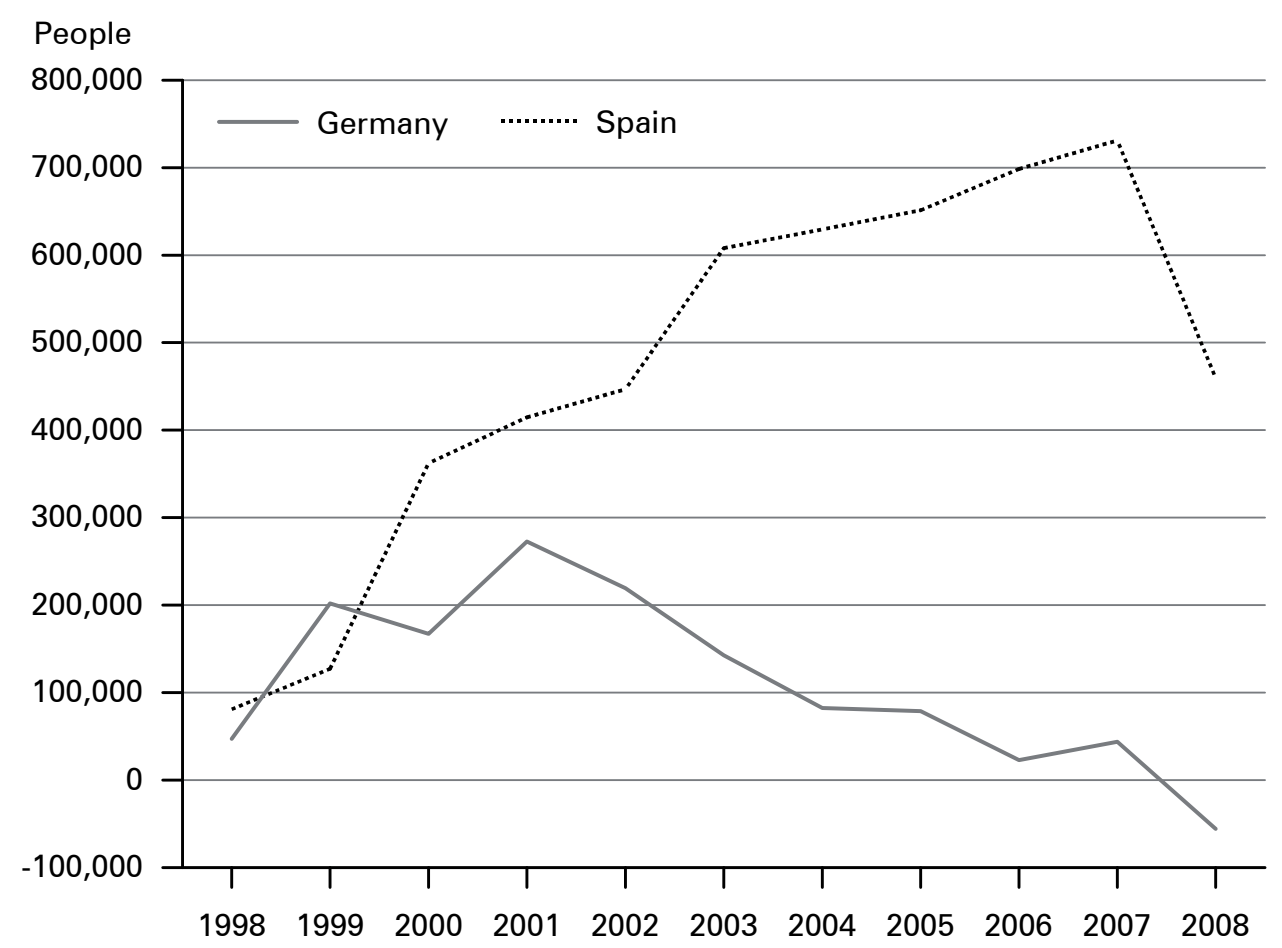

Source: Eurostat International Migration and Asylum Statistics

2 For German and Spanish reactions to the crisis, see also the "Ad-Hoc Query on the actions/ policy measures taken in migration management as the reaction to global crisis" of 22 July 2009 http://emn.sarenet.es/Downloads/prepareShowFiles.do?entryTitle=4.\%20EMN\%20AdHoc\%20Queries 
for immigrants from the new EU Member States in the enlargement waves of 2004 (eight out of ten new Member States) and 2007 (Romania and Bulgaria). Spain used a two-year transitional period in both cases, and has thus created unrestricted access to the labour market for citizens from the new EU Member States since 2009, but has since reversed its position.

As a consequence of these different migration policies, immigration has taken on distinctly divergent features in the recent past. Immigration grew strongly in Spain during the economic boom, and particularly between 2000 and 2007, while Germany's net immigration was exceptionally low, in comparison both to Spain and to earlier periods of Germany's post-war migration history (see Fig. 2).

The percentage of the foreign population in Spain has been higher than that in Germany since 2006 due to the recent massive influx (see Fig. 3). Germany has experienced peak immigration on various occasions in the past, and has consolidated a permanent presence of foreign nationals (Loeffelholz 2002).

It should be noted that the Spanish figures also include a large share of the irregular resident population. Municipal registration is possible regardless of migration status, and enables access to be had to basic healthcare services, and may serve as a proof of residence in case of a regularisation campaign (González-Enríquez 2009). In Germany, municipal registration is only possible for regular migrants (Cyrus

Fig. 3: Percentage of the foreign population in Germany and Spain, 2000-2009

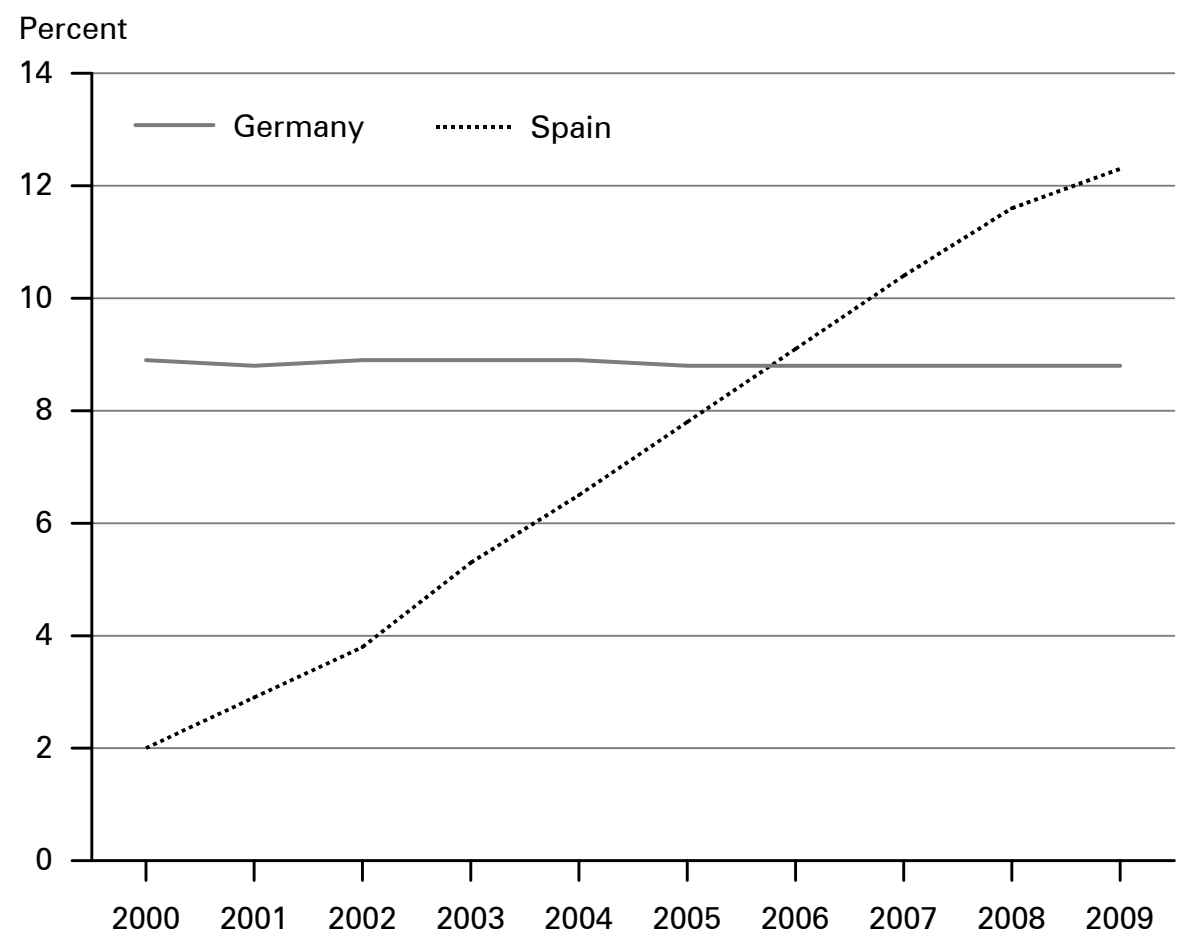

Source: own calculation based on Eurostat International Migration and Asylum Statistics 
2009: 9). However, estimates indicate low numbers and a declining trend for the irregular resident population in Germany. If we recalculate the percentage of foreign nationals in Germany for 2009 to include the maximum estimate of irregular migrants of 330,000 by Vogel and Gelbrich (2010), the percentage of foreign nationals in the population increases only slightly, from 8.8 to $9.1 \%$.

The immigration profiles of the two countries are different. Spain's immigration is dominated by labour motives and migrants of non-European origin (with Romania forming the most relevant exception). The settlement duration of most immigrants is still short; activity rates are high and education levels relatively low (at least in terms of recognized qualifications). Among non-European origins, the Latin American countries have been dominant, and language barriers are low in most of these cases. In Germany's immigrant population, most foreign nationals have been residents for a longer time and come from non-German-speaking countries. Former immigration peaks in the 1960s (migration from Turkey) and the late 1980s to the early 1990s (migration from Eastern Europe) constitute the principal factors influencing the current population of foreign citizenship.

While both countries' immigration consists of inflows mainly triggered by labour demand, family reunification, educational purposes and asylum-seeking, it is in Spain that labour demand has played and continues to play a more important role (see Table 2).

Tab. 2: $\quad$ Valid permits by reason in Germany and Spain, 2009 (\%)

\begin{tabular}{lrr}
\hline Reason & Germany & Spain \\
\hline Total & 100.0 & 100.0 \\
Family reasons & 36.7 & 19.7 \\
Educational reasons & 3.2 & 1.4 \\
Remunerated activities reasons & 1.8 & 29.8 \\
Other reasons & 58.3 & 49.1 \\
\hline
\end{tabular}

Source: own calculation based on Eurostat International Migration and Asylum Statistics

\section{Institutional structures of the labour market}

Labour market outcomes are a result of the interplay between supply and demand in a market that is heavily influenced by the institutional features of the labour market. ${ }^{3}$

3 The institutional settings of national labour markets can introduce significant differences in terms of how supply and demand will interact and produce market outcomes (Bassanini/Duval 2006; Furceri/Mourougane 2009). The most relevant aspects are unemployment benefits, tax wedges, wage bargaining systems, active labour market programmes, minimum wage floors and short-time working schemes (Jean/Jiménez 2007). Labour market outcomes for migrants are also influenced by these general institutional aspects (Jean et al. 2007). 
The State influences conditions by legislating minimum conditions and providing (or not providing) effective institutions for the enforcement of such conditions, as well as by providing unemployment benefit schemes and active labour market policies. In addition, the strength and organisational structures of trade unions shape the wage-setting process and influence whether employees can find help in case their employment rights have been violated. The combined effect of such factors is crucial for labour market outcomes, although it is debatable as to which features in the complex interaction are most important.

The OECD developed a summary indicator of employment protection strictness, including 21 basic items which can be classified in three main areas: (i) protection of regular workers against individual dismissal; (ii) regulation of temporary forms of employment; and (iii) specific requirements for collective dismissals. The information refers to employment protection provided through legislation and as a result of enforcement processes. Both Germany and Spain reduced their levels of protection strictness during the nineties, but still differ from less highly-regulated economies such as the United States. The United States show the lowest value in this indicator among OECD countries in 2008 (0.85), while Spain (3.11) has a slightly higher level of protection than Germany (2.63). This latter difference is due to stricter regulation of temporary forms of employment in Spain than in Germany, and not to the protection of permanent workers against (individual) dismissal or specific requirements for collective dismissal. Although temporary workers may be protected effectively during their contracts, this does not protect workers from unemployment when their contract runs out in a period of employment reduction. This has major implications for understanding the different effects had by the crisis in the German and the Spanish labour markets respectively. ${ }^{4}$

To explain such differences, we propose to conceptualise the labour market as consisting of three segments, ${ }^{5}$ with considerably higher entry barriers between segments than within segments:

- The permanent segment, characterized by permanent contracts. This is dominated by a high proportion of relatively well-skilled, well-paid jobs, many of which are in manufacturing and the public service. Older employees dominate, either because they acquired permanent contracts before the liberalisation of the labour market, or because temporary entry-level jobs lead to permanent employment.

4 As Bentolila et al. (2010: 322) point out, "there are good reasons for suspecting that this EPS index, based as it is on legal norms and not on usual application, is misleading in the Spanish case. The de facto employment protection strictness in temporary employment is much lower in Spain than in France, while the opposite applies to EPS in permanent employment" [translation by the authors]. They add (p. 323) that in Spain "there are no restrictions de facto: The authorities hardly supervise whether firms comply with established conditions for temporary contracts" [translation by the authors].

5 The degree of segmentation is often referred to in discussions about these issues as 'dualism', given that only two segments are differentiated (Jean et al. 2007: 22). We prefer to speak of labour market segmentation rather than of dualism. 
- The temporary segment, characterized by fixed-term contracts. This includes entry-level jobs in all sectors, and is specifically important in sectors such as the services, construction and agriculture, where wage and labour conditions are generally less favourable than in manufacturing and the public service. As new entrants to the labour market, younger employees and migrants are overrepresented.

- The informal segment, characterized by the absence of formal contracts. This is dominated by low-paid jobs requiring low skill levels, mainly in construction, agriculture and services, with a considerable proportion of domestic work in private households, virtually all of which is part of the informal economy.

Spain and Germany differ considerably with regard to the importance of these labour market segments. The size of the informal economy is difficult to measure, but there are some indications that it is bigger in Spain than that in Germany. ${ }^{6}$ Temporary employment in Spain was more than twice that in Germany in 2006 (34.1 as against $14.5 \%$ of all employees). The percentage declined sharply in Spain to about $25 \%$, indicating that net job losses were much more pronounced in the temporary segment. The percentage remained constant in Germany, this possibly being explained by the fact that job losses in the temporary sector balanced with employers' reluctance to commit themselves to new permanent contracts due to the crisis (see Fig. 4).

Job losses in the permanent segment in Germany were mitigated by short-time working schemes. Such programmes give incentives to employers to adjust to temporarily lower production levels by cutting the numbers of hours worked instead of cutting the numbers of persons employed (OECD 2010). Such programmes are highly effective when it comes to their mitigating effects when lower production levels are really temporary as expected, but they may also delay the impact of the crisis and make it more persistent (Duval et al. 2007: 25). As export production soon recovered in the crisis, short-time work subsidy schemes are considered to have worked well in this crisis in Germany (Myunghee Kim 2010: 93). While 1.5 million workers were in short-time working schemes by May 2009, their number decreased to 0.8 million by December the same year (Statistisches Bundesamt 2010).

Labour market segmentation also indicates that the economic recession affected the gender composition of the migrant workforce differently. Researchers pointed out in a recent IOM report (Koehler et al. 2010) that male-dominated sectors such as construction (in the temporary or informal segment) have seen a rising unemployment rate, while more female-dominated sectors such as healthcare (in the permanent segment) still demand continuing inflows of labour. As a consequence, more women than men immigrated to EU countries during the economic crisis. The

6 There are different indicators of the share accounted for by the informal economy. Unfortunately, there are reliability problems with all the indicators, and many indicators are available for either Spain or Germany, but not for both. See Andrews et al. for a discussion of measurement issues and the available indicators (2011). 
Fig. 4: Temporary employees as a percentage of the total number of employees in Germany and Spain, 1998-2009 (\%)

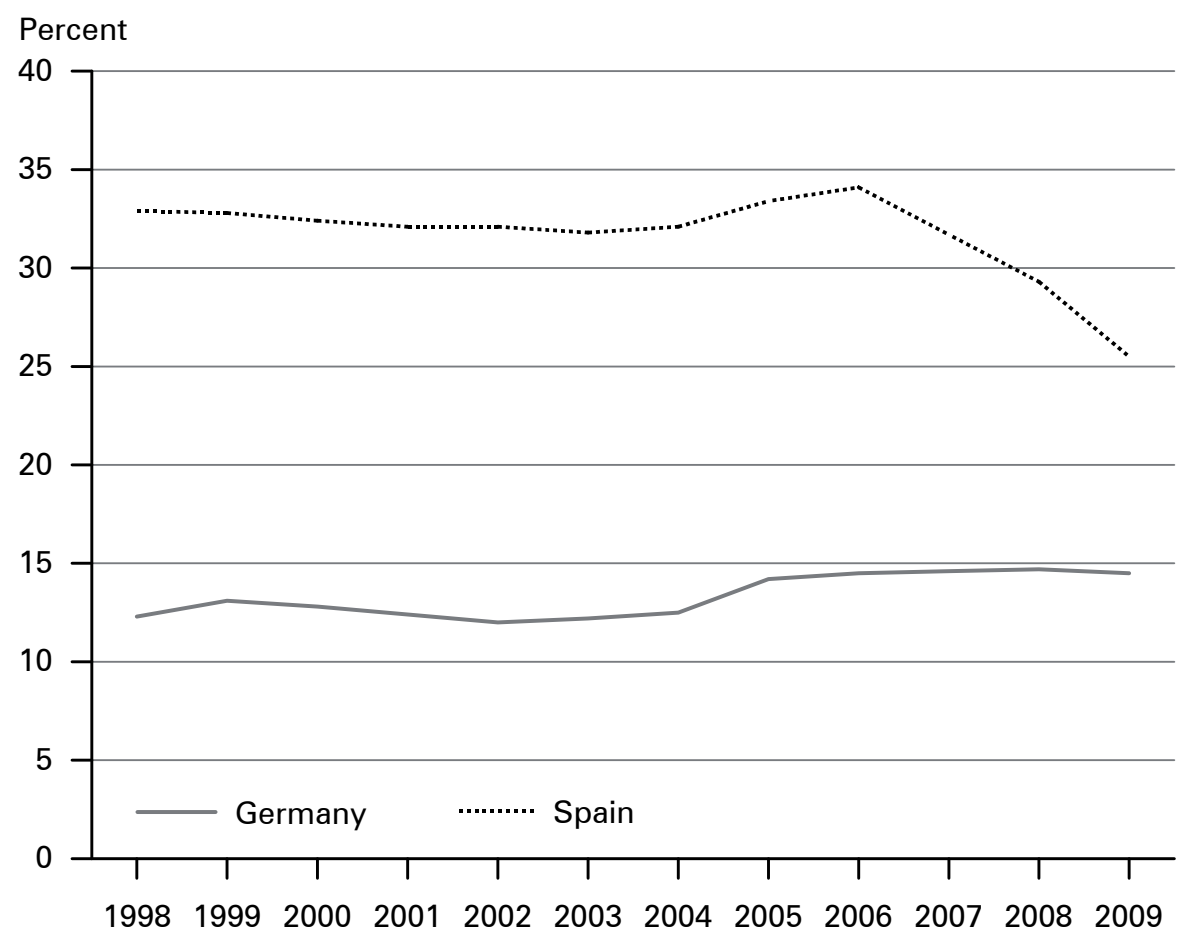

Source: Eurostat Labour Force Surveys

percentage of female foreign workers among the total foreign workforce rose in Spain from $49 \%$ to 53 \% between 2007 and 2009 (Koeh/er et al. 2010: 21), while in Germany the high growth rates of unemployment are in those traditionally strong German industries (such as electrical and automobile manufacturing) in the permanent segment which are dominated by a native male workforce. Consequently, the German government subsidized a job protection programme targeting this group (Koehler et al. 2010). Meanwhile, it is also suggested that migrant workers adjust to the worsening employment situation by switching to other labour market segments. Migrant construction workers were believed to seek employment in the self-employed informal segment in Spain, which led to a $15 \%$ increase in the labour force in agriculture and services in 2009 compared to that of 2008 (Koehler et al. 2010: 21).

Immigrant integration policies in the labour market, defined as specific policies promoting labour market integration (for example courses for occupational skill adjustment), have not been analysed in detail for this article. Although the arguments that have been put forward indicate the strong presence of other factors than integration policies, integration policies may play a significant role in the aftermath of the crisis. Economic restructuring takes place more rapidly during an economic crisis, and immigrants who came to fill job vacancies with lower skill requirements 
may find it difficult to adjust to changing labour markets. In addition, new immigrants continue to arrive during the crisis for reasons such as family unification. Experts warn that the timing of such immigration causes a lasting 'scarring effect' as skills deteriorate if new immigrants do not find immediate access to the labour market (Papademetriou et al. 2010: 16). For them, integration programmes are of major importance. As a consequence of the fiscal consolidation born out of the crisis, many public services and also integration programmes are reduced. The Spanish Government cut the national budget dedicated to integration policies by $50 \%$ between 2009 and 2010 (Ferrero-Turrión/López-Sala 2010: 179).

\section{$5 \quad$ Labour market integration of immigrants}

Labour market integration implies economic convergence between the native and foreign populations. Only employment and unemployment are used as indicators in this brief overview.

Foreigners are usually harder struck in times of economic recession than natives. Among migrants, recent entrants to the labour market are usually more strongly affected by economic downturns, and this is more the case if recent entrants are only offered temporary jobs. This is the case in Spain, where many recently arrived migrants were offered temporary jobs and lost them during the crisis because a large share of the employment adjustments operated through the temporary segment of the market.

Figure 5 shows in comparative terms how employment of own nationals and foreign nationals (including EU citizens) has developed in Germany and Spain since the late 1990s.

The figure shows that employment growth was positive in both countries from 1998 to 2007, with a higher intensity in Spain. While only $14 \%$ of employment growth in Germany went to foreigners, this proportion was $39 \%$ in Spain. The official estimation of the Spanish Government (Oficina Económica del Presidente de Gobierno 2006) shows that immigration was responsible for $40 \%$ of GDP growth between 2001 and 2005, and also contributed to employment growth among nationals. The crisis reduced the employment of nationals in Spain to 2004 levels, while in Germany employment of nationals started to grow from 2004 onwards. The differences during the last phase of the crisis are striking, and are featured separately in Figure 6.

The economic crisis reduced employment in both countries, at a lower intensity in Germany when compared to the extensive job destruction that took place in Spain. The Spanish economy shed $9.5 \%$ of total employment between 2008 and 2010 (second quarter), while Germany created $0.4 \%$ of additional employment (EU-27 average: -2.2 \%). Employment destruction in Spain affected foreigners with a particular ferocity $(-13.3 \%)$. In Germany, on the other hand, foreign employment grew by $2.4 \%$ in these two years and national employment by only $0.3 \%$. 
Fig. 5: Employment by nationality in Germany and Spain, 1998-2009 (thousands)

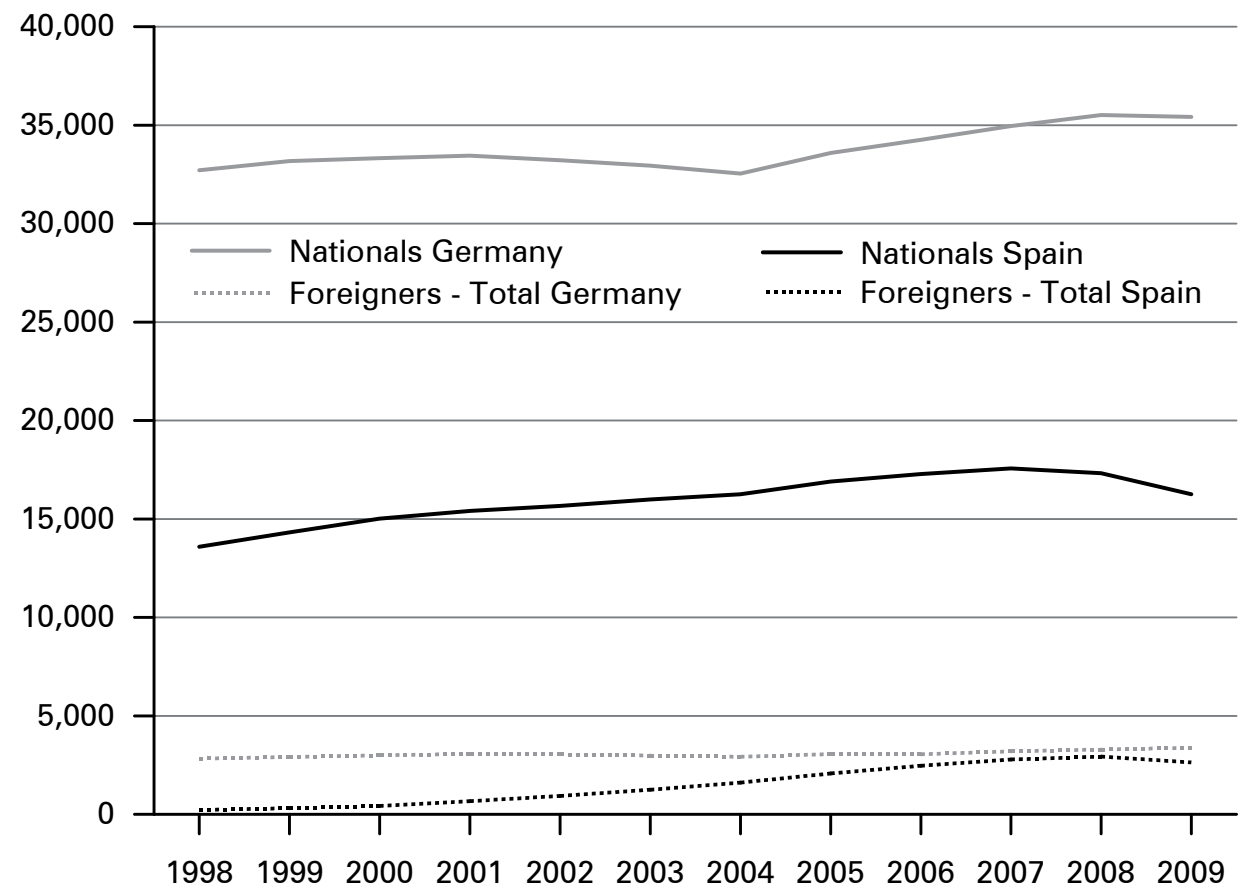

Source: own calculation based on Eurostat Labour Force Surveys

Differences in unemployment rates between foreigners and nationals are positive and substantial in both countries (see Fig. 7). These gaps have been persistent over the last ten years in Germany, while in Spain foreign nationals had similar unemployment rates as own citizens until the crisis and unemployment rocketed from 2007 onwards. Meanwhile, the unemployment rate for foreign nationals reached almost $30 \%$ in Spain in 2009, while, the unemployment rate for foreigners in Germany was about $15 \%$. One reason is that migrant-concentrated economic sectors (such as construction) accounted for a large proportion of unemployment in Spain, while in Germany "foreign workers were under-represented in the industries that were hardest hit by the economic crisis" (such as metal production or car manufacturing) (Koehler et al. 2010: 19-20). It is noted moreover that unemployment also increased rapidly among Spanish people, reaching about $16 \%$. Immigrants in Spain were more severely affected by the crisis, but the difference between nativeborn and foreign nationals is still more pronounced in Germany, when measured in 
Fig. 6: Employment growth by nationality in Germany and Spain (\%, 2nd quarters 2008-2010)

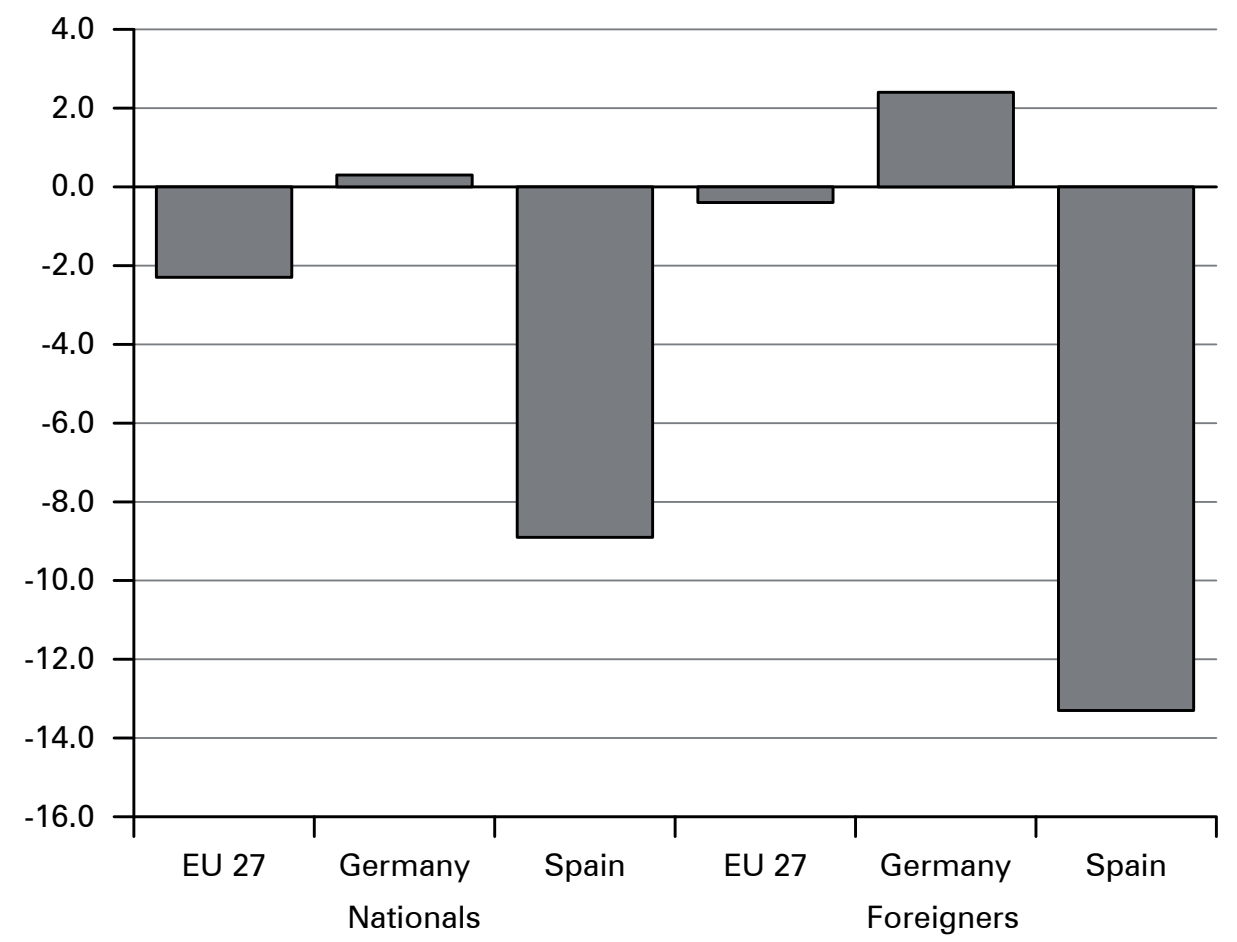

Source: own calculation based on Eurostat Labour Force Surveys

relative terms. ${ }^{7}$ The "wild ride" (Bentolila et al. 2009: 1) of labour market outcomes in Spain is not limited to foreign workers. It is a common attribute and affects all workers in the extensive temporary segment of the market. The strictness of employment protection in the permanent segment is partially compensated for by the flexibility provided by the temporary segment.

$\overline{7}$ If measured in absolute terms (differences in percentage points between foreign and own nationals), the employment gap widened most strongly in Spain (Papademetriou et al. 2010: 10). 
Fig. 7: Unemployment rates by nationality in Germany and Spain, 1998-2009 (\%)

Percent

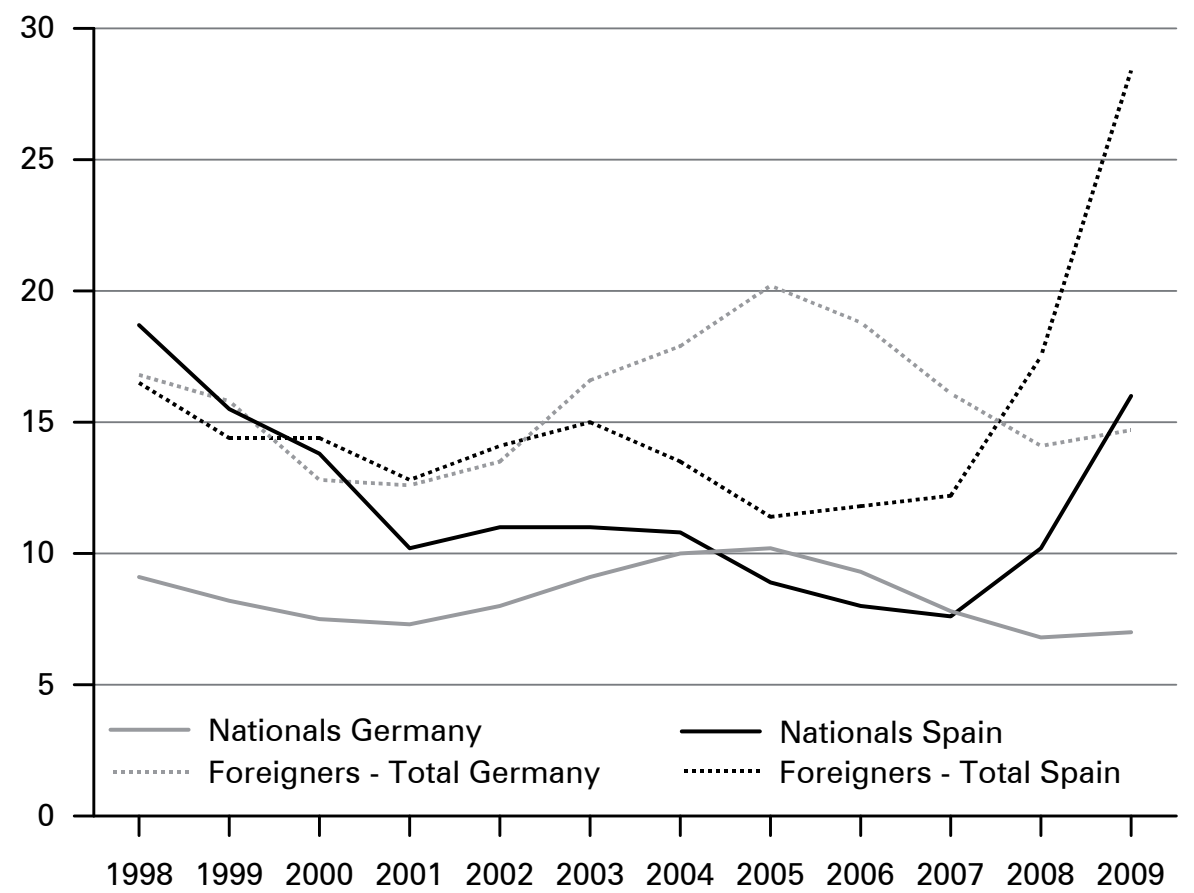

Source: Eurostat Labour Force Surveys

\section{The public discourse on migration}

It is commonly assumed that migrants may easily become scapegoats in times of economic crisis because of the increasingly fierce job competition between foreigners and nationals. The increasing popularity of the British National Party and the outbreak of wildcat strikes 'British jobs for British workers' in the UK in February 2009 show the severe impact of the economic crisis on the public discourse on migrants. Given the differentials in economic development in Spain and Germany, one expects negative public attitudes towards, more heated debates about and more grave concerns over migration in Spain than in Germany. However, evidence suggests that public attitudes towards migration did not change dramatically in the course of the economic recession.

The current economic crisis has amplified the voices of those who have always been sceptical of the benefits of immigration, as a panel of experts concludes after analysing developments in several countries including Germany and Spain (Papademetriou et al. 2010: 15). People who considered immigration more of a problem than an opportunity increased by between 4 and 9 percentage points between 2008 
and 2009 in several European countries (German Marshall Fund of the United States et al. 2009: 6). This number increased by five percentage points in Germany, reaching $44 \%$ of the survey participants - an increase but not really a striking change. Spain was not included in the survey until 2009 , and revealed that $58 \%$ of respondents saw immigration as rather problematic.

However, the same survey indicates that immigration does not really score high among most respondents' current concerns. ${ }^{8}$ What is strikingly different is the opinion of the Government's capacity to manage migration: $71 \%$ of respondents in Germany thought that their Government was doing a good or fair job, while only 33 of the Spanish sample had a positive opinion of their Governments' management capacities (German Marshall Fund of the United States et al. 2009: 23). To a certain degree, the economic recession even replaced migration as a focus of concern in the public discourse in some countries where migration was an issue of high salience in the pre-crisis period (such as Spain and the UK) (Koehler et al. 2010: 23).

Right-wing parties have so far not successfully mobilised along xenophobic lines in Spain. Issues of restricting migration and blaming migrants have come up during electoral campaigns, but right-wing parties have received less than $1 \%$ of votes in recent elections. Media debates peaked in 2006, when the number of boat people arriving rapidly increased, without taking on major momentum since the economic crisis (see Fig. 8).

Major political debates in the EU Member States are sketched in the yearly reports of the National Contact Point of the European Migration Network. ${ }^{9}$ There are no reports of major debates having been triggered by the economic crisis in Germany and Spain, in 2008 and 2009, but rather by ongoing legislative and institutional debates (e.g. on the Spanish Act on Immigration in 2008 and 2009) and extraordinary news events (e.g. following the killing of a German by young men of foreign origin in 2008 in Germany). The media's framing of migration-related issues is regarded as a contributing factor to the negative public attitudes towards migration. For example, a recent study of the media coverage of British Muslims between 2000 and 2008 reveals that $36 \%$ of media stories about British Muslims were related to terrorism, and that migrants (especially Muslim migrants) are therefore perceived in the media discourse as being associated with threat and danger (Moore et al. 2008). There were coinciding debates in both Spain and Germany on integration problems of immigrants with a Muslim background in 2010, with debates on relaxing restrictions for the immigration of highly-skilled labour migrants in Germany. The debate on the integration of Muslim immigrants evolved around the book Deut-

8 One-third of German and two-thirds of Spanish respondents named the economy as the most important problem facing the country today, with immigration being indicated by only $7 \%$ as a key issue after some other topics such as education. At the same time, similar percentages indicate that they are worried about legal migration (Germany: $29 \%$; Spain: $22 \%$ ) or illegal migration (Germany: $63 \%$; Spain: $71 \%$ ).

9 http://emn.sarenet.es/Downloads/prepareShowFiles.do?entryTitle=1.\%20Annual\%20Policy\%20Reports 
Fig. 8: Evolution of public opinion on immigration as a personal or general problem for Spain

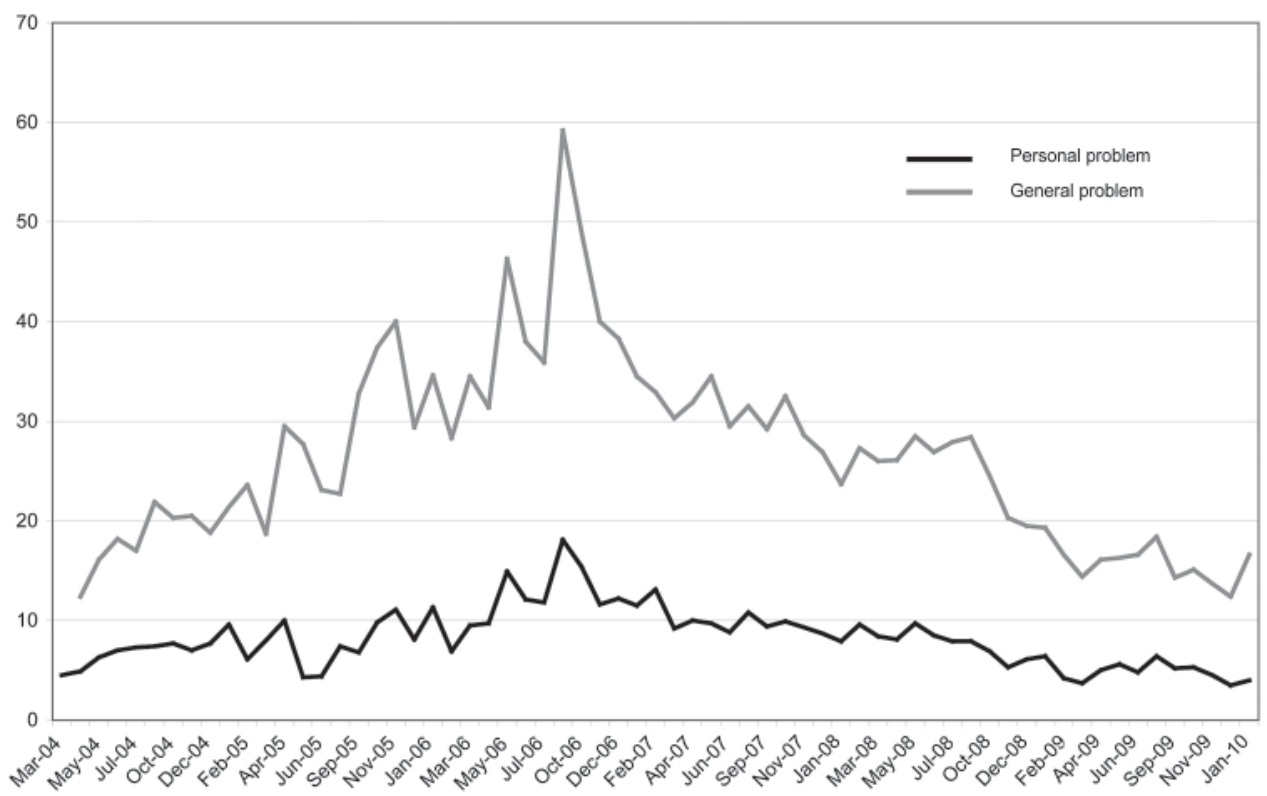

Source: Ferrero-Turrión/López-Sala 2010: 178

schland schafft sich ab (Germany Abandons Itself) penned by the former socialdemocratic national bank leader Thilo Sarrazin (2010). The presentation as 'taboo breaking' was welcomed by considerable parts of the population, while researchers and immigrant organisations criticized the book for its mixture of one-sided presentation of evidence, hostility towards immigrants and xenophobia rooted in popular prejudice. For example, the Expert Council of German Foundations on Integration and Migration characterized the debate as being detached from the facts and partly xenophobic, while indicating that their survey on integration showed a more pragmatic, relaxed attitude among large sections of the population (SVR 2011: 28). However, the German debates are more heavily dominated by a theme of socio-cultural integration than by economic considerations (Habermas 2010; Pfaff 2010). The main topic of public and political debates in Spain focuses on irregular migrants, and easily mixes labour market integration with cultural issues (e.g. Moroccans).

\section{Conclusions}

Germany and Spain have experienced highly-divergent impacts of the crisis on the labour market in general, and on immigrant workers in particular. This can be mainly explained by looking at the economic growth patterns prior to the crisis. Spain's higher, more labour-intensive growth was enabled by growth in the labour supply 
that was fuelled by immigration, and fostered by an immigration policy that was de facto permissive, while restrictive migration policy prevented labour supply growth in Germany and encouraged more capital-intensive growth in which low-skilled nationals, and particularly immigrants, found it difficult to integrate. We therefore conclude that institutional features of the labour market promoted these patterns. The high importance of the temporary and informal labour market segments in Spain, which were hardest hit by the crisis, led to the vulnerable position of immigrant and young workers.

The economic crisis has made parts of the population more sceptical about immigration. However, there appear to be no links between the severity of the crisis and public debates on migration. Although Spain was definitely harder hit by the crisis than Germany, and immigrants were more severely affected, public debates on migration and integration issues seem to be at least as fierce in Germany as in Spain. In the German case, one can expect that due to the low impact of the crisis on labour market outcomes public debates do not push migration and integration issues to the fore. As a result of the crisis, migration policies have been changed in the Spanish case, and these legislative endeavours have drawn public attention. However, the legacy of past migrations and migration policies has a more significant impact on the public perception of migration as a risk than economic factors do.

\section{References}

Andrews, Dan; Caldera Sánchez, Aida; Johansson, Åsa 2011: Towards a Better Understanding of the Informal Economy. In: OECD Economics Department Working Papers 873. OECD Publishing. [URL: http://dx.doi.org/10.1787/5kgb1mf88x28-en, 10.11.2011].

Bassanini, Andrea; Duval, Romain 2006: Employment patterns in OECD countries: reassessing the role of policies and institutions. In: OECD Economics Department Working Papers 486. [URL: http://dx.doi.org/10.1787/846627332717, 1.9.2010].

Bentolila, Samuel; Cahuc, Pierre; Dolado, Juan 2009: Two-Tier Labor Markets in a Deep Recession: France vs. Spain. In: 2009 FEDEA Annual Policy Conference, Madrid, 28-30 October 2009. [URL: http://www.crisis09.es/monografia2009/pdf/01-bentolila.pdf, 1.9.2010].

Bentolila, Samuel; Cahuc, Pierre; Dolado, Juan; Barbanchon, Thomas 2010: Paro y empleo temporal durante la crisis: Una comparación entre Francia y España. In: FEDEA (Eds.): La Crisis de la Economía Española. Análisis Económico de la Gran Recesión. Monografías Madrid: FEDEA: 311-350. [URL: http://www.crisis09.es/libro_crisis/la_ crisis_de_la_economia_espanola.pdf, 9.11.2010].

Cyrus, Norbert 2009: CLANDESTINO Country report Germany: Undocumented Migration Counting the Uncountable. Data and Trends across Europe. December 2008, Revised 2009. [URL: http://www.irregular-migration.hwwi.net/Country_reports.6114.0.html, 1.10.2010].

Duval, Romain; Elmeskov, Jörgen; Vogel, Lukas 2007: Structural policies and economic resilience to shocks. In: OECD Economics Department Working Papers 567. [URL:http://dx.doi.org/10.1787/140152385131, 1.9.2010]. 
European Migration Network 2010: EMN Ad-Hoc Query. [URL: http://emn.sarenet.es/ Downloads/prepareShowFiles.do?entryTitle $=4 . \% 20$ EMN\%20Ad-Hoc\%20Queries, 1.9.2010].

European Migration Network 2010: Annual Policy Reports. [URL:http://emn.sarenet.es/ Downloads/prepareShowFiles.do?entryTitle=1.\%20Annual\%20Policy\%20Reports, 1.9.2010].

Eurostat 2010: International Migration and Asylum Statistics. [URL: http://epp.eurostat. ec.europa.eu/portal/page/portal/population/introduction, 17.10.2010].

Eurostat 2010: National Accounts. [URL: http://epp.eurostat.ec.europa.eu/portal/page/ portal/national_accounts/introduction, 17.10.2010].

Eurostat 2010: Labour Force Surveys. [URL:http://epp.eurostat.ec.europa.eu/portal/ page/portal/labour_market/introduction, 26.10.2010].

Ferrero-Turrión, Ruth; López-Sala, Ana 2010: Country report Spain. In: International Organization for Migration (Eds.): Migration and the Economic Crisis in the European Union: Implications for Policy. Brussels: International Organization for Migration: 161-181.

Furceri, Davide; Mourougane, Annabelle 2009: How do institutions affect structural unemployment in times of crisis. In: OECD Economics Department Working Papers 730. [URL: http://dx.doi.org/10.1787/220734255421, 1.9.2010].

German Marshall Fund of the United States et al. 2009: Transatlantic Trends: Immigration. Key findings 2009. Washington, DC: German Marshall Fund of the United States. [URL: http://www.gmfus.org/trends/immigration/index.html, 2.9.2010].

Godenau, Dirk 2010: Irregular migration in Spain since the turn of the millennium - development, economic background and discourses. In: Irregular Migration Database. Hamburg Institute of International Economics Working Paper 6/2010. [URL: http:// irregular-migration.hwwi.de/Working-papers.6113.0.html, 1.10.2010].

González-Enríquez, Carmen 2009: CLANDESTINO Country report Spain: Undocumented Migration Counting the Uncountable. Data and Trends across Europe. December 2008, Revised 2009. [URL: http://www.irregular-migration.hwwi.net/Country_reports.6114.0.html, 1.10.2010].

Habermas, Jürgen 2010: Leadership and Leitkultur. In Z NET. 31 October 2010. [URL: http://www.zcommunications.org/leadership-and-leitkultur-by-j-rgen-habermas, 13.11.2011].

Koehler, Jobst; Laczko, Frank; Aghazarm, Christine; Schad, Julia 2010: Migration and the Economic Crisis in the European Union: Implications for Policy. Brussels: International Organization for Migration.

Jean, Sébastien; Causa, Orsetta; Jimenez, Miguel; Wanner, Isabelle 2007: Migration in OECD countries: Labour market impact and integration issues. In: OECD Economics Department Working Papers 562. [URL: http://dx.doi.org/10.1787/164604735126, 2.9.2010].

Jean, Sébastien; Jiménez, Miguel 2007: The unemployment impact of immigration in OECD countries. In: OECD Economics Department Working Papers 563. [URL: http:// dx.doi.org/10.1787/162425722235, 2.9.2010].

Loeffelholz, Hans Dietrich von 2002: Beschäftigung von Ausländern - Chance zur Erschließung von Personal- und Qualifikationsreserven. In: Mitteilungen aus der Arbeitsmarkt- und Berufsforschung 35,4: 628-644. 
Moore, Kerry; Mason, Paul; Lewis, Justin 2008: Images of Islam in the UK: The representation of British Muslims in the national print news media 2000-2008. In: Channel Four Web Site 7. July 2008. [URL: http://www.channel4.com/news/media/pdfs/Cardiff\%20 Final\%20Report.pdf, 21.11.2010].

Myunghee Kim, Anna 2010: Country report Germany. In: International Organization for Migration (Eds.): Migration and the Economic Crisis in the European Union: Implications for Policy. Brussels: International Organization for Migration 81-102.

OECD 2010: Labour markets and the crisis. In: OECD Economics Department Working Papers 756. [URL: http://ideas.repec.org/p/oec/ecoaaa/756-en.html, 2.9.2010].

Oficina Económica del Presidente de Gobierno 2006: Inmigración y economía española: 1996-2006. [URL: http://www.lamoncloa.gob.es/NR/rdonlyres/62B6B50E-AE7B-455A85A5-600EF4EA9281/80515/InmigracionYEconomiaEspaniola12Nov.pdf, 1.10.2010].

Papademetriou, Demetrios G.; Sumption, Madeleine; Terrazas, Aaron 2010: Migration and Immigrants Two Years after the Financial Collapse: Where Do We Stand?. Migration Policy Institute, Washington D.C.. [URL: http://www.migrationpolicy.org/pubs/ MPI-BBCreport-2010.pdf, 09.11.2011].

Pfaff, Carol W. 2010: Multilingual Development in Germany in the Crossfire of Ideology and Politics. In: Okulska, Urszula; Cap, Piotr (Eds.): Perspectives in Politics and Discourse. Amsterdam: John Benjamins Publishing Co. 327-358.

Roig Vila, Marta; Castro Martín, Teresa 2007: Childbearing Patterns of Foreign Women in a New Immigration Country: The Case of Spain. In: Population (English Edition) 62,3:351-379. [URL: http://www.jstor.org/stable/pdfplus/27645314. pdf?acceptTC $=$ true, 18.7.2011].

Sarrazin, Thilo 2010: Deutschland schafft sich ab: Wie wir unser Land aufs Spiel setzen. München: Deutsche Verlagsanstalt.

Statistisches Bundesamt 2010: Der Arbeitsmarkt im Zeichen der Finanz- und Wirtschaftskrise. In: Wirtschaft und Statistik 3/2010. Wiesbaden: Statistisches Bundesamt: 237-247.

SVR 2011: Migrationsland 2011, Jahresgutachten 2011 mit Migrationsbarometer, Sachverständigenrat für Migration und Integration (SVR). Berlin. [URL: http://www.svr-migration.de/wp-content/uploads/2011/04/jg_2011.pdf, 9.11.2011].

Vogel, Dita; Gelbrich, Stephanie 2010: Update report Germany: Estimate on irregular migration for Germany in 2009. Hamburgisches WeltWirtschaftsInstitut. Database on Irregular Migration. Dezember 2010. [URL: http://irregular-migration.hwwi.de/ typo3_upload/groups/31/4.Background_Information/4.5.Update_Reports/Update_report_Germany_2010.pdf, 9.11.2011]. 
A German translation of this reviewed and authors' authorised original article by the Federal Institute for Population Research is available under the title "Arbeitsmarktintegration und öffentliche Wahrnehmung von Migranten: Ein Vergleich zwischen Deutschland und Spanien während der Wirtschaftskrise", DOI 10.4232/10.CPOS-2011-13de or URN urn:nbn:de:bib-cpos-2011-13de3, at http://www.comparativepopulationstudies.de.

Date of submission: 21.07.2011

Date of Acceptance: 19.01.2012

Dr. Dirk Godenau ( $₫$ ). Universidad de La Laguna, Tenerife, Spanien.

E-Mail: dgodenau@ull.es. URL: www.ull.es

Dr. Dita Vogel. Hamburgisches Weltwirtschaftsinstitut, Hamburg, Deutschland.

E-Mail: vogel@hwwi.org. URL: http://www.hwwi.org

Vesela Kovacheva. Hamburgisches Weltwirtschaftsinstitut, Hamburg, Deutschland.

E-Mail: kovacheva@hwwi.org. URL: http://www.hwwi.org

Dr. Yan Wu. Swansea University, Swansea, Wales, UK. E-Mail: y.wu@swansea.ac.uk URL: http://www.swansea.ac.uk 


\section{Comparative Population Studies - Zeitschrift für Bevölkerungswissenschaft}

wWw.comparativepopulationstudies.de

ISSN: 1869-8980 (Print) - 1869-8999 (Internet)

Published by / Herausgegeben von

Prof. Dr. Norbert F. Schneider

Federal Institute for Population Research

D-65180 Wiesbaden / Germany

Managing Editor /

Verantwortlicher Redakteur

Frank Swiaczny

Editorial Assistant /

Redaktionsassistenz

Katrin Schiefer

Language \& Copy Editor (English) /

Lektorat \& Übersetzungen (englisch)

Amelie Franke

Copy Editor (German) /

Lektorat (deutsch)

Dr. Evelyn Grünheid

\section{Layout / Satz}

Beatriz Feiler-Fuchs

E-mail: cpos@destatis.de

\author{
Scientific Advisory Board / \\ Wissenschaftlicher Beirat \\ Jürgen Dorbritz (Wiesbaden) \\ Paul Gans (Mannheim) \\ Johannes Huinink (Bremen) \\ Marc Luy (Wien) \\ Clara H. Mulder (Groningen) \\ Notburga Ott (Bochum) \\ Peter Preisendörfer (Mainz)
}

\section{Board of Reviewers / Gutachterbeirat} Martin Abraham (Erlangen) Laura Bernardi (Lausanne) Hansjörg Bucher (Bonn) Claudia Diehl (Göttingen) Andreas Diekmann (Zürich) Gabriele Doblhammer-Reiter (Rostock) Henriette Engelhardt-Wölfler (Bamberg) E.-Jürgen Flöthmann (Bielefeld) Alexia Fürnkranz-Prskawetz (Wien) Beat Fux (Zürich) Joshua Goldstein (Rostock) Karsten Hank (Köln) Sonja Haug (Regensburg) Franz-Josef Kemper (Berlin) Michaela Kreyenfeld (Rostock) Aart C. Liefbroer (Den Haag) Kurt Lüscher (Konstanz) Dimiter Philipov (Wien) Tomáš Sobotka (Wien) Heike Trappe (Rostock) 